Western University Scholarship@Western

Political Economy Research Group. Papers in

Political Economy

Economics Working Papers Archive

1996

\title{
Inflation Control and Monetary Policy Rules
}

David Laidler

Follow this and additional works at: https://ir.lib.uwo.ca/economicsperg_ppe

Part of the Economics Commons

Citation of this paper:

Laidler, David. "Inflation Control and Monetary Policy Rules." Political Economy Research Group. Papers in Political Economy, 66. London, ON: Department of Economics, University of Western Ontario (1996). 
POLITICAL

ECONOMY

RESEARCH

GR (O) P

\section{PAPERS IN POLITTCAL ECONOMY}

Paper No. 66

"Inflation Control and Monetary

Policy Rules"

David Laidler

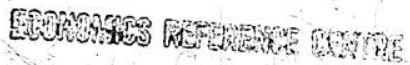 \\ JAB 241003

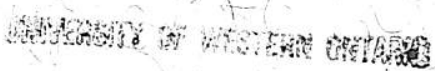


The Political Economy Research Group was established in the faculty of Social Science at the University of Western Ontario in 1988. Its purpose is to foster scholarship, teaching and interdisciplinary research in political economy, with a focus on:

1. the application of economic models and methods to the study of : political processes and institutions,

2. the economic impact of political processes and institutions;

3. the influence of economic factors on the formation of public policy and on institutional change,

4. the politics of economic policy màking,

5. the political, social, and economic effects of public policy.

Có-directors:

Ronald Wintrobe (Economics)

Robert Young (Political Science)

Board of Directors:

Peter Howitt (Economics)

B.B. Kymlicka (Political Science)

John N. McDougall (Political Science)

Peter Neary (History)

John Whalley (Economićs)

Staff:

Jayne Dewar

For further information:

Political Economy Research Group,

Department of Economics,

Social Science Centre,

London, Ontario, Canada N6A 5C2

phone: (519) 661-3877.

fax: (519)' 661-3292 
ISSN:

1181-7151

ISBN:

0-7714-1848-5

43296

\title{
Inflation Control and Monetary Policy Rules*
}

\author{
by \\ David Laidler \\ University of Western Ontario \\ and \\ C.D. Howe Institute
}

Revised November 1995 


\section{Introduction}

If the 1990s turn out to be the decade in which a quarter century of world-wide inflation comes to an end, that will be because policy-makers have finally digested the message that inflation is a monetary phenomenon and a costly one at that. It will also be because institutional arrangements that permit price level behaviour to become the main concern of central banks have been, or are in the process of being, put in place. Though details differ widely across countries, it is a fair generalisation that in the last few years central banks have been granted (or have taken) increasing autonomy in the day to day conduct of monetary policy at the same time as they have become more single minded about the control of inflation.

A particularly visible example of these tendencies is to be found in the European Union, where, as a preliminary step to the creation of a European System of Central Banks, the central bank laws of a number of countries have recently been amended to include an explicit price stability mandate as well as provisions to insulate their officers from political influence; and where the proposed European Central Bank will be organised on similar principles. In New Zealand, a new central bank law provides that the elected government and the Reserve Bank shall enter into a formal contract that sets explicit quantitative targets for price level behaviour. The same forces are also at work in other countries in less dramatic ways. For example, in Canada there is now in place an explicit agreement between the government and the Bank of Canada which specifies quantitative targets for the inflation rate; though, in this case, the agreement is in no way required by the central bank law, and could be terminated without resort to legislation of any sort. In Britain too, the government has introduced inflation targets, and mechanisms have been 
put in place that provide for regular consultations between the Chancellor of the Exchequer and the Governor of the Bank of England, whose minutes are published with a "time lag". These mechanisms also call for the Bank to publish a quarterly inflation report whose content is not subject to Treasury control. However, though these measures have considerably enhanced the Bank of England's independent influence on policy, crucial tactical decisions, notably those involving setting interest rates, remain in ministerial hands.

It is tempting to characterise such developments as these as representing a triumph for "Monetarism", so called. To the extent that this doctrine always did emphasise the monetary nature of inflation, and the desirability of subjecting the conduct of monetary policy to clear cut rules, this is accurate enough, but it is misleading to stop here. Over the past twenty years there have been important developments in both monetary theory and the theory of central banking, which have ensured that the ideas whose influence is so patently obvious in the current situation are significantly different from those described, for example, in Thomas Mayer's (1978) survey of monetarist doctrine.

This paper explores the nature of those ideas, and their relationship to monetarism. It begins with a brief account of monetarism as it stood in the $1960 \mathrm{~s}$, just as inflation was beginning to get under way. It goes on to discuss what, with benefit of hindsight, seem to have been important weaknesses in that doctrine: namely, the inadequacy of its theory of money for dealing with normative questions about the costs of inflation, and the initial narrowness of its focus when it came to the treatment of inflation expectations and policy credibility. It analyses the different senses in which the phrase "monetary policy rules" may be used, stressing in particular the relationships linking various policy rules to the political principle that the agents who undertake policy measures should be accountable 
to those whom their measures affect. Finally, the implications of the discussion for the appropriate configuration of the monetary policy regime are outlined.

In two important respects, this paper is selective in its coverage. First, it is concerned with monetary policy and the control of inflation under central banking. It does not discuss the economics of hypothetical "free banking" regimes such as Selgin and White (1994) have recently surveyed. That is not because this missing material is uninteresting, but because I am here concerned with the economics that has underlain the actual evolution of policy over the last few years. Also, I pay no explicit attention to the role of exchange rate regimes, taking it for granted that there exists a regime under which national or, in the case of the proposed European system, supra-national, central banks are, in fact, free to make meaningful choices about inflation. Thus, some sort of floating rate lies in the background of the discussion.

A fixed exchange rate is, of course, a monetary rule of sorts, and unless rigidly and perpetually fixed, it is a rule that can be abandoned in certain circumstances. From the perspective of this paper, however, the rule in question is crucially incomplete, inasmuch as it leaves open the question of what form of monetary organisation underpins the stability of the currency or basket of currencies against which the exchange rate is fixed. ${ }^{1}$ The issues involved here, not to mention the principles to be observed in deciding how and when to adjust a pegged exchange rate are nevertheless important and interesting. The only valid reason for not dealing with them here is that one can only cover so much in one paper. $^{2}$ 


\section{The Monetarist View of Inflation and Its Control}

The word "monetarism" was introduced into our vocabulary at the end of the 1960s to describe an already coherent body of macroeconomic doctrine. Monetarism thus existed prior to the onset of serious inflation in western economies, and though its subsequent evolution might have been a response to that inflation, its initial development was not. Empirical studies of inflation were important in early monetarist literature, but the episodes in question seemed remote from then recent American and European experience, and therefore to cast only an indirect light on it, mainly by establishing the apparent ubiquity of an empirically stable aggregate demand function for money. ${ }^{3}$ That monetary policy seemed to matter very much indeed for rapid inflations was interesting, but this result did not necessarily disturb then mainstream preconceptions about its lack of relevance for cyclical fluctuations which were taking place against a background of creeping (allegedly for cost-push reasons) inflation. It was monetarism's claim that creeping inflation was just as much a result of monetary expansion as was rapid inflation, and even more its claim that the cycle was also a monetary phenomenon, that were hard for that mainstream to accept.

Though this did not become clear until the mid-1970s, underlying early monetarism, or rather Friedman's version of it, was a macroeconomic model conventional in its overall structure: - IS-LM plus Phillips curve -, but special in its particular configuration: - a stable, rather interest-insensitive demand for money function, a supply of money controllable by the authorities, and a Phillips curve that included endogenous inflation expectations among its arguments, with a unit coefficient. In any economy that was well described by such a model, though cyclical fluctuations could still occur because 
of real shocks, their amplitude would in all likelihood remain modest unless money growth also fluctuated. ${ }^{4}$ At the same time, the inflation rate would vary around an average value given by the money growth rate minus the real growth rate adjusted for the long-run real income elasticity of the demand for money. That is why the proposal, advanced by Friedman (1960), to reduce, by a legislated rule, monetary policy to the maintenance of a constant rate of growth for the money supply was also integral to monetarism. The case for a constant money growth rule was not that it was in any technical sense an optimal policy, but rather that its implementation would avoid major real fluctuations while simultaneousiy maintaining long run price stability. That one could do better in principal was never denied, given enough knowledge about the actual economy's structure, and about the time lags to which policy effects were subject; but serious doubts about being able to do better in practice, given policy-makers' ignorance of these matters, made a powerful case for not trying.

In the 1960s monetarism was controversial in its positive claims about the causes of cyclical fluctuations and creeping inflation; but, on the normative front, though the policy means--the money growth rule--it suggested was also controversial, the policy ends it advocated--price stability combined with minimal real fluctuations - were completely conventional. In the light of subsequent experience, the absence of debate about the desirability of price level stability in the early 1960 s is worth highlighting. It was only late in the decade, once inflation had taken off, that the appropriateness of living with it began to be widely canvassed. And it was only with inflation's persisting for another two decades that the once universally accepted goal of price level stability became a minority taste. Prominent among the reasons for this was no doubt the reluctance of politicians to 
set a goal whose achievement would require temporary, but no less serious for that reason, contractions in real income and employment, and the closely associated reluctance of many economists to advocate unpopular policies with a slim chance of being implemented. ${ }^{5}$ Paradoxically, however, a specific characteristic of monetarist doctrine also contributed to the attractiveness of a policy of living with inflation: namely, the absence of any careful analysis of money's functions in the theory of the demand for money which monetarism inherited from Friedman.

Friedman (1956) modelled the demand for real balances "as if" they were a consumer durable good, and his (1959) empirical formulation of the demand for money function was a special case of his permanent income hypothesis of consumption. It was a natural extension of this approach, pioneered by Martin Bailey (1958), to treat inflation "as if" an indirect tax levied on the services of this durable good, and to measure inflation's social costs as the area of a triangle, or trapezium, under its demand function. Friedman's (1969) paper on the "Optimum Quantity of Money" developed this approach further, and showed not merely that fully anticipated inflation reduced economic welfare, but also that, in the case of non-interest bearing fiat money, welfare would actually be maximised where the price level fell at a rate equal to the economy's real rate of interest. The key insight underlying this result was that under a fiat money regime, as opposed to one in which money was a real commodity with alternative uses, the marginal social cost of real balances was zero; hence, it would be appropriate to drive the private opportunity cost of holding them to zero.

Friedman himself did not seriously argue that the Federal Reserve System, or any other central bank, should aim at a secularly falling price level, and hịs basic argument, 
considered in isolation, certainly did nothing to strengthen tolerance for ongoing inflation. One minor extension of that argument, however, to an economy in which the money stock was dominated by interest bearing bank deposits did just that. In such an economy, if it really is appropriate to measure the economic impact of anticipated inflation "as if" it acts as a tax on the services of a durable good, then the only costs of inflation would arise from agents economising on their holdings of that component of the money stock consisting of non-interest bearing currency. On these assumptions, the welfare costs of anticipated inflation, to say nothing of the tax yield associated with it, though still positive would verge on the negligible. Moreover, and crucially, the assumptions in question are not far fetched. A competitive banking system would pay market determined interest rates on its deposit liabilities, and these rates would vary with the inflation rate. Measures to eliminate monopoly power in banking, that its to say, would seem to do almost as much to reduce the welfare costs of ongoing inflation as the elimination of inflation itself. ${ }^{6}$

In the light of this conclusion, any dynamic cost benefit calculation of the type pioneered by Phelps (1967), in which the short run output and employment costs of bringing inflation down are compared to the long term benefits accruing from having a lower, rather than a higher, stable and predictable inflation rate, seemed to lead inescapably to the conclusion that, once inflation had become embedded in the economy, the welfare maximising policy was probably to stabilise inflation and to live with it, while enforcing competition in banking. To the extent that this solution was complicated by the existence of contracts entered into before inflation began, as well as by other, not always very well specified, nominal rigidities, resort to indexation seemed to be called for as a supplementary measure. 
If monetarists were too uncomfortable with these conclusions ever to adopt them, and, with the exception of those concerning indexation, they were, their Keynesian opponents were more than willing to point out their apparent inconsistency in failing to do so. James Tobin's often quoted 1977 observation that, "It takes a heap of Harberger triangles to fill an Okun gap," persuasively summarised the Keynesian position, and it was hard to disagree. ${ }^{7}$ Something (or things) have clearly changed in the last 20 years to produce an intellectual underpinning for the configurations of monetary policies that we now observe. As I shall argue, the things in question were two in number: first, we have learned to pay much more careful attention than we once did to the complexity of the role played by the monetary system in a market economy, and to the implications of that complexity for the concept of anticipated inflation; and second, we seem, in large measure, to have worked out the implications of our insights about these matters for the design of monetary-policy rules and their place in the policy regime.

\section{The Role of Money, The Absence of Indexation and the Costs of Inflation}

To treat money "as if" a consumer durable good was a masterstroke as far as advancing our positive understanding of monetary phenomena was concerned. Once Friedman had suggested doing so, economists' attention shifted from armchair debates about why agents might hold money, and what that implied for the interest elasticity and overall stability of the demand for money function, to econometric work designed to provide empirical answers to these and related questions. If some of that early work seems in hindsight to have been naive, it nevertheless laid the groundwork for a permanent advance in our knowledge about these matters. This argument by analogy, however, 
neglected money's fundamental social importance as a means of exchange and unit of account, both for current transactions as well as those involving the passage of time. Interpreted literally, the standard macroeconomic models of the 1960s and 1970s had markets functioning without monetary exchange; and information about the structure of relative prices underlying the aggregates with which they dealt was apparently disseminated and processed without reference to the economies to be realised from the use of a reliable numeraire. This characterisation is as true of the sticky price IS-LM model, as of the flexible price New-classical framework that replaced it, including its "overlapping generations" variant. ${ }^{8}$ Both types of model proved to be treacherous guides to normative questions about the social costs of inflation.

An older tradition in monetary theory, dating back to Carl Menger (1892) and beyond his work to such 18 th century writers as Adam Smith (1776), did, however, pay careful attention to money's role in market processes. From 1964 onwards, attempts to renew interest in, and indeed add to, the insights it yielded, while simultaneously linking those insights to monetarist empirical work on the demand for money, formed an important element in the monetarist research agenda of Karl Brunner and Allan Meltzer (e.g. 1964, 1971), an agenda which had been influenced not only by Friedman, but crucially in this respect, by their UCLA colleague Armen Alchian and later by Axel Leijonhufvud. Furthermore, in the mid 1970s, papers questioning the relevance of the "shoe leather cost" model of inflation's costs in the light of money's unit of account and means of exchange role began to appear..$^{9}$ The work in question focused on money's central function as a unit of account and standard of deferred payment in disseminating information and incentives, and as a means of exchange in mediating trade in goods and 
services, and raised questions about the effects of inflation upon its capacity to perform these functions. It noted the tenuous correspondence of the theoretical concept of "fully anticipated" (i.e. expected and completely adjusted to) inflation to the complex phenomena associated with ongoing inflation in an actual economy, and therefore drew attention to the resulting scope for costly resource misallocations to arise from ongoing inflation's effect on the capacity of relative prices to convey accurate information and incentives to agents.

At roughly the same time, there also appeared Jo Anna Gray's important (1978) paper on the destabilising effects of indexed wage contracts in the face of real shocks to the economy. This work attracted immediate attention and quickly undermined economists' optimism about the extent to which indexation could safely be deployed to turn an ongoing inflation into something more closely resembling a fully anticipated process. And in any event, as the 1970 s and 1980s progressed, it gradually became apparent that the introduction of indexation on any widespread scale, even in areas such as taxation or capital market transactions, where it would not be destabilising, was simply not going to happen. Whether the reasons for this were political or technical is irrelevant in the present context. It was the consequences which were important.

Accounting standards and taxation systems which largely took the stability of the economy's unit of account for granted remained in place throughout those decades, when, in many countries, inflation remained in the high-single-low-double-digit range, with well known results: standard debt contracts become "front-end loaded" as nominal interest rates rose to offset the real depreciation of capital values, giving borrowers strong incentives to shift towards projects promising high short term gains; while inflation itself created private 
profit opportunities of dubious social value, and scarce resources, not least human resources, were diverted to their exploitation. As Howitt (1990) in particular has stressed, these effects fell not only on the level of real output but its rate of change too, to the extent to which resources were diverted from technical research and development activities that might otherwise have led to productive innovations. And in labour markets, inflation seemed to be associated with a higher level of industrial conflict. ${ }^{10}$

Ongoing inflation, in short, has turned out to do a great deal more than wear out a little shoe-leather. Even so, earlier assessments of the transitional costs involved in lowering inflation still seem to be valid; and so the foregoing arguments do not, in and of themselves, provide a sufficient reason for choosing price level stability as a goal for monetary policy. If even stable inflation is much more costly than we once thought, and if stability becomes harder to sustain the higher is the average rate of inflation, our assessment of what is a tolerable upper limit for the inflation rate might well be revised downwards. But these factors, whether considered separately or in combination, do not also require that any ongoing inflation would best be reduced to zero. Indeed, many responsible commentators, in full awareness of their importance, have nevertheless expressed a preference for a more modest goal. Thus, at the 1991 Bank of Japan Conference, Stanley Fischer (1993 p. 43) advocated inflation targets in the 2-4 percent range, and John Taylor (1993 p. 6) noted, quite accurately, that there was no consensus at that conference as to whether this, or a lower range, was preferable. ${ }^{11}$

\section{Expectations and Policy Credibility}

The choice between price stability and low inflation does not hinge upon 
comparing the gains to be realised in the long run by sustaining a stable inflation rate in the region of zero, rather than, say, 3 per cent. The ultimate aim of price stability or low inflation targets is to render the operations of the price mechanism more efficient, and such targets are more likely to have that effect if agents believe in their durability. Advocates of eliminating inflation argue that a stable price level is a potentially durable policy goal, in a way that a low but stable positive inflation rate is not, and that its adoption will have a significant effect on expectations that would be hard to achieve by announcing a low inflation goal. Qualitatively speaking, their argument is compelling, but in the current state of knowledge, it is hard to see how the magnitude of the gains to be realised from the extra credibility of a price stability goal can be quantified.

Lucas's (1972) introduction of Muth's (1961) rational expectations idea into macroeconomics, and Sargent and Wallace's (1976) application of it to the modelling of monetary policy, laid the foundations for a notable advance in economic understanding. $^{12}$ This is so despite, indeed because of, the fact that the apparent policy implications of the rational expectations hypothesis which first attracted widespread attention in the late 1970 s and early 1980 s went badly wrong in a number of countries. The hypothesis had seemed to imply that monetary tightening, designed to lower the inflation rate, would succeed in doing so without significant transitional unemployment effects, only provided that it was clearly pre-announced. Thus, for example, Robert E. Lucas Jr. was quoted by Time (August 27, 1979, p. 29) as follows: "Ideally we should announce a monetary expansion policy of $4 \%$ annually for the next seven years and then stick to it. People would respond, and inflation would be cured with a minimal risk of a deep recession." That is not how things subsequently worked out in practice. Neither in 
the United States, nor in the United Kingdom, for example, were the inflation reduction policies of the early 1980 s implemented by stealth, but in each case their most apparent early consequence was recession. Announcement effects, it was soon realised, were unreliable.

To change behaviour, statements of good intentions on the part of the authorities must be believed and acted upon. This requires not just that they be heard, but also that listeners find it plausible that the authorities will indeed keep their promises, and that the listeners in question are free to act upon that belief. The question of "credibility" must therefore be at the forefront of any discussion of the role of expectations in the transmission of the effects of policy. ${ }^{13}$ The claim, that price stability is credible as a long run goal for monetary policy in a way that a merely low inflation rate cannot be, is said to follow from the fact that when long run costs and benefits alone are considered, price stability becomes an unequivocal choice. ${ }^{14}$ Only when transitional costs and benefits associated with output and employment fluctuations are brought into the picture might some other goal come to look attractive. Hence, the announcement of a low inflation, as opposed to a price stability, target is also an announcement that, in the design and day-today execution of their policies, the monetary authorities are concerned with more than price level behaviour; it therefore signals that their commitment to a particular inflation target is less than whole-hearted.

There are a number of ways of elaborating on this point. It is, for example, well known that, starting from a current positive inflation rate, a dynamic cost-benefit analysis that considers transition costs will yield a particular long-run target inflation rate above zero, and a time path along which that target will be asymptotically approached. Let us 
suppose, for the sake of argument, that a policy based upon such a cost-benefit analysis is feasible; but let us also note that inflation's time path is not, as every agent must surely know, just the outcome of monetary policy. It is subject to non-monetary shocks too. Suppose, then, that before a long run inflation target has been achieved, some such shock moves inflation upward. Unless this shock is transitory, its occurrence will presumably require a recomputation of the subsequent optimal time path for inflation, and delay the date at which the low target inflation rate is ultimately to be achieved, or to be more precise, at which inflation comes within some specified interval above that target. A downward shock, on the other hand, might move the relevant date forward. Also, once the long run target has been reached, a subsequent shock would put inflation on a path along which transition costs (or benefits) would again become relevant, so that its target value would be restored only gradually.

Moreover, as Marty and Thornton (1995) in particular have stressed, any asymmetry of response to such short-run considerations as we have been discussing here would likely place more emphasis on costs than on gains and could lead to an upward drift in the inflation rate. To the extent that such asymmetry is predictable, and the literature, to which Barro and Gordon (1983) was a seminal contribution, dealing with time inconsistent policies suggests it will be, a low inflation target loses credibility. As Governor John Crow of the Bank of Canada put it in the 1988 Hanson Lecture (Crow 1988) which heralded Canada's price stability programme:

"... success in what is in effect an attempt to mimic price stability by achieving a stable inflation rate depends on strong public confidence that the authorities would not accept a further acceleration in the rate of inflation. However, if the authorities 
were unwilling to act to get the rate of inflation down from, for example, 4 per cent, why should anyone believe that they would be anymore willing to get it back to 4 percent if for one reason or another upward pressures on prices led the inflation rate to rise to 5 per cent?"

Under a regime in which transition costs are ignored and a price stability goal is set, to be achieved by a certain date and thereafter maintained, non-monetary shocks will not cause that goal to be revised. Rather, in their wake, the authorities will have to take whatever action is necessary to return the price level to its target level (or rather into its target range) as quickly as possible. Expected price level behaviour over any particular planning horizon, which is what matters for improving the efficiency of market mechanisms, is thus likely to be subject to less uncertainty when transitional costs are ignored in the setting of long-run targets for price level behaviour than when they play a role.

At first sight, the suggestion that the authorities take no account of monetary policy's output and employment effects seems quite unrealistic. As Fischer (1994) in particular has stressed, monetary policy does affect such variables, and it seems unreasonable to pretend otherwise. In fact, however, this is not quite what is involved here. A policy regime that explicitly aims at medium term price level stability must quantify its target in terms of a range, rather than a precise number, for a particular measure of the price level (or its rate of change) and a time period over which the chosen target variable's value is to be averaged. The wider the range in question, and the longer the period of averaging, the more room will such a target allow for the price level to absorb short-run shocks that might otherwise create fluctuations in output and employment. 
Thus, a medium term price stability target, even when it is the sole explicit goal of policy, can be designed to provide a degree of automatic cushioning against such shocks.

What is important to the credibility of such a regime, however, is that its adoption gives a clear signal that the authorities have no intention of trying to optimize policy subject to some short-run output-inflation tradeoff. Earlier, we assumed for the sake of argument that a policy of this type was feasible, but I am aware of no evidence to suggest that traditional monetarist scepticism about this matter is anything other than fully justified. To put it simply, arguments that justify the formal inclusion of output and employment among the targets of monetary policy on the grounds that to do otherwise would be nonoptimal are beside the point when the quantitative knowledge necessary for the design and implementation of optimal policies is lacking. ${ }^{15}$ A policy regime that explicitly recognizes this will surely be more credible than one which pretends otherwise.

Questions about the public's confidence in its expectations of the future behaviour of the price level are also central to the issue of whether, when a policy target is selected, it should specify the pursuit of a given target range for the price level over time, or merely given bounds for the change of the price level, looking forward from any particular moment. ${ }^{16}$ At first sight, the latter choice seems preferable. To the extent that nonmonetary shocks are capable of shifting the price level upward from time to time, it seems as if it would be unnecessarily costly to insist that monetary policy be used to reverse their effects. And a commitment to do so would introduce extra variability into short-term inflation expectations into the bargain. However, a policy regime that did not offset such shocks would cause the price level to follow a random walk over time, and hence introduce greater variability into long-term inflationary expectations. If long-run 
predictability of price level behaviour is important, then this property is surely decisively undesirable, and a target path for the price level seems to be called for. Moreover, to set a target path for the price level rather than the inflation rate also reduces the temptation to a central bank to take short-term risks on inflation. If such risks do generate inflation, that is a bygone under an inflation target, but not under a price level target. A bank will be less likely to take inflation risks if it knows that this exposes it to the chance of having to impose a perhaps painful restrictive policy in the future. ${ }^{17}$ This point is important, because it suggests that the price level's random walk characteristic under inflation targeting might become significant at time horizons shorter than McCallum (1995) suggests.

In the longer run, we might also expect the credibility of a price level stability regime to help reduce the very nominal stickiness from which some of the transitional costs (benefits) of inflation reduction (increase) derive in the first place, and which underlies many arguments on the side of settling for a low positive inflation rate in the long-run. Marty and Thornton (1995) have observed that positive inflation will indeed act as a lubricant to the allocative mechanism in the event of downward stickiness of money wages and prices, as Tobin (1972) argued, but they have also noted that it is hard to see what, other than expectational phenomena, might underpin the institutional rigidities which cause such stickiness, and that perhaps these are malleable in the face of credible policy.

Two important caveats are nevertheless in order here, because economic policy principles are not much use unless they can be translated into practice, and abstract debates about policy credibility can easily take on a somewhat other-worldly character. First, price level measurement issues are crucial when policies are actually implemented, 
and they can be quite serious enough to blur the distinction between zero and merely low inflation as Fortin's (1990) study of these issues showed. Given the biases inherent in most price indices, price stability in practice probably means a measured inflation rate in the $0-2$ percent per annum range. ${ }^{18}$

Even more important, there are many other threats to the credibility of monetary policy than the prospect of non-monetary shocks to the price level and its rate of change. Consider the threat of future inflation implicit in chronically imbalanced budgets: For example, in Canada the public debt/GDP ratio, Federal and Provincial debt combined, currently stands at about 100 per cent. Even a quite small probability that some of this debt might be monetarized at some time in the future is damaging to the credibility of that country's inflation control regime. I would hazard a guess that it is, in fact, far more damaging than the fact that an indefinitely long commitment to inflation in the 1-3 percent range has recently replaced a previous promise that, after 1995, a target inflation rate of "clearly less than 2 percent" would be sustained. ${ }^{19}$ Here we have a telling example of why the qualitative strength of arguments for the extra credibility of price stability targets that undoubtedly exists in principle sometimes needs to be viewed with a little scepticism in practise.

\section{Monetary Policy Rules}

A target value for a variable that is to be sustained indefinitely into the future is one of the things we might signify when we speak of a "policy rule". Indeed, when Henry Simons (1936) wrote of "Rules versus Authorities in Monetary Policy" a price level rule of just this kind was what he had in mind, and when the phrase "policy rule" is used in 
this sense, it is easy to attain wide agreement that rule guided policy is preferable to the alternative. ${ }^{20}$ Who, after all, would support monetary policy that delivered unstable and unpredictable behaviour for a key economic variable such as the general price level? Nevertheless, this whole issue of "rules versus discretion" needs further discussion, because the phrase "monetary policy rule" has taken on a number of meanings over the years, as has its converse "discretionary policy". We have, for example, already touched upon a second sense in which the phrase "monetary policy rule" is used in our earlier discussion of Friedman's (1960) constant money growth rate proposals.

It is still as true as it ever was that the effects of monetary policy are subject to "long and variable lags", and for some observers this observation still implies that, however desirable it might be to aim at price level (or inflation) stability, this target is so far removed along the causative chain that links it to the instruments actually under the authorities' control, that it is unwise to anchor monetary policy to a rule for its behaviour. If mistakes are made, or if the authorities covertly abandon their target, this will not become apparent, so it is argued, until it is approximately two years too late to do anything about it; better, then, to cast a policy rule in terms of the behaviour of some intermediate variable which experience shows to be a leading indicator of the price level. A monetary aggregate is the typical choice here, and Friedman's above-mentioned constant money growth rate regime is the archetype of this version of a monetary rule. However, the proposals of Bennett McCallum (e.g. 1988) and Allan Meltzer (e.g. 1987) to make money growth, not a constant, but a lagged function of velocity, represents an important variation on this theme.

When we discuss the issue of "rules versus discretion" in this specific context, 
there is a good deal to be said in favour of discretion, always provided that we are careful how we use the word. It is surely not arguable, and it ought not to be argued, that discretionary, in the sense of capricious, manipulation of some monetary policy instrument might produce a better outcome than adherence to a rule. It is however a defensible position that a policy regime which permits the authorities to use discretion, in the sense of their best judgement, in influencing money growth in pursuit of a precisely defined inflation target might be preferable to having it tied down by a rule for its behaviour. For example, Friedman's constant growth rate rule is vulnerable to the charge that it ignores questions raised by the fact of ongoing institutional change and its effect on any chosen monetary aggregate. And, although the McCallum-Meltzer variation on the theme is designed to ensure that money growth does indeed respond appropriately to those long run swings in velocity which one might expect institutional evolution to produce, there still remains the question of how much scope for surreptitious evasion of any rule might be presented by the fact that some institutional developments involve the introduction of new monetary instruments which then need to be attributed to one monetary aggregate or another. A case against even these more sophisticated money growth rules may be mounted along these lines.

The contrast between a money growth rule and a discretionary regime is not in any event quite as clearcut as it might seem at first sight. No monetary aggregate that includes commercial bank liabilities is under the direct and determinate control of the monetary authorities, and to keep it on a pre-determined path must involve manipulation, and discretionary manipulation at that, of policy instruments that are directly under the authority's control. Only a rule for the growth rate of the central bank's own balance sheet 
is an exception here, which is why some advocates of monetary policy rules have moved in this direction. This latter proposal raises other problems, however, not least that to lay down a rule for the behaviour of the quantity of high powered money would be to deprive the authorities of the flexibility that they might need to perform another of their tasks, namely to act as a lender of last resort. One wonders how the 1987 stock market crash might have evolved in the presence of such constraints on central bank behaviour; and one might also question the wisdom of introducing them now, when the effects of the rapid growth of derivatives markets on the robustness of the financial system is still an open question. $^{21}$

Meltzer (1994) has recently proposed a way of dealing with problems of this sort, that self-consciously harks back to the discount policy espoused by Walter Bagehot in Lombard Street (1873). A rule for the growth rate of unborrowed high-powered money could be combined with a discount window open to borrowers at a penalty interest rate. In normal times, discount facilities would remain unused, but in an emergency they would operate at the discretion of would-be borrowers without the need formally to suspend existing restrictions on Central Bank behaviour. To say that Meltzer's proposal blurs the distinction between a rule guided and a discretionary regime is not to criticise it. ${ }^{22}$ On the contrary, it comes to grips with a special case of a problem that is quite general with quantitative rules for the behaviour of any monetary aggregate: namely, that one can always think of reasons why it might be desirable to suspend them from time to time, and that when such an occasion arises, someone must use their best judgment in bringing that suspension about. In Meltzer' case, the someone is eligible borrowers; but perhaps the authorities would also have to exercise judgment in ensuring that criteria for eligibility 
kept pace with institutional developments.

Be that as it may, it can be objected that the forgoing discussion fails to address certain components of the case for money growth rules that follow from rational expectations models of monetary policy. In such models, agents who are aware of the parameters determining the time series behaviour of the money supply can and do use that knowledge in forming the expectations upon which they base their own decisions. It might seem, then, that to allow the monetary authorities to use discretion in varying that behaviour removes an important source of valuable information, and hence stability, from the economy's structure.

The force of this argument depends once more upon what one means by "discretion". Certainly capricious monetary policy will introduce unnecessary and damaging uncertainty into private sector decision making. But suppose that the monetary authorities are free to act according to their best judgement in order to aim at a well defined time path for the price level, and that, as is the case in the abovementioned rational expectations models, it is the behaviour of the price level that agents need to be able to forecast. In such a case, if those making monetary policy were better informed than private sector agents about variability of the linkages running from the instruments they control to the ultimate price level target, then to tie them down to a money growth rule rather than leaving them free to use their better information, would make private sector agents worse off. And if there was nothing to choose between the knowledge of the authorities and the private sector, then the latter would, given knowledge of the ultimate goal of policy, be able to forecast the policies that the authorities own best judgement would lead them to choose, and a money growth rule would be redundant. Only when the 
non-bank public knows more about the monetary transmission mechanism than the monetary authorities might a rule be desirable, for in this case the best judgement of ill informed monetary authorities might well yield inferior policy.

There is, though, a little more to be said about this matter, for in the actual world there will usually be differences in the information available to policy makers and various groups in the private sector, and differences of opinion among them about just what policy measures are appropriate to the maintenance of price stability. It is, moreover, extremely unlikely that informational advantages will always lie with the same group. For example, judgements about whether shocks to the system are permanent or transitory, and if the latter, for just how long they might persist, are, as Brunner and Meltzer (1993) have stressed, particularly difficult to make. In these circumstances, when the interaction between policy makers and the private sector is an ongoing affair, it would surely be helpful to the latter to know how the monetary authorities are likely to behave in each specific instance. Even those who, like myself, are sceptical of the appropriateness of tying them down with a rule, should be willing to concede the desirability of having them adopt and adhere to a widely understood operating procedure, supplemented by frequent and clear public statements about their own interpretation of specific circumstances and their planned response to them. ${ }^{23}$

\section{Accountability and Autonomy}

No-one would deny that monetary policy can exert enormous power, for good or ill, over the fortunes of those who are subject to it. This simple fact forms the starting point for virtually all arguments for bringing the monetary authorities under democratic 
control, and these arguments often seem to point to the desirability of a regime whereby discretionary monetary policy is run by a branch of a finance ministry answerable to an elected assembly. ${ }^{24}$ Such arrangements are hard to reconcile with rule based monetary policy; and indeed, when monetary policy is placed in the hands of elected politicians, and the central bank is given the status of just another government department, the likely outcome is widely believed to be higher and less stable inflation than any of the arguments presented earlier in this paper would lead us to think desirable. That, of course, cannot, in and of itself, be sufficient reason for opposing such arrangements: if the electorate ask for and receive an outcome that the economist would not recommend, then so much the worse for the economist. The crucial point, however, is that this outcome may not be what the electorate wants, and it is precisely this possibility that enables us to reconcile the case for monetary policy rules with the time honoured principle that those who wield power should be accountable to those whom their actions affect.

In representative democracies, agents vote for political programmes, not isolated measures, and immediate benefits conferred on relatively small and well defined groups of agents seem to do more to attract support than small costs widely dispersed across the community at large do to deter it; and if the costs are uncertain in any event, then their deterrent effect on voters is further reduced. The ordinary processes of representative democracy tend to produce an array of government expenditure programmes targeted at particular interest groups, financed by taxes levied on the community at large. Furthermore, the likely inflationary consequences of keeping taxes low, resorting to deficit finance, and then to a little monetization of debt, are not widely understood even among sophisticated electorates, so these too become tempting policy options. ${ }^{25}$ Add to this the 
political popularity of promoting high employment, taken in conjunction with inevitable uncertainty about just how hard such policies can be pushed by monetary means before they spill over into inflation, and one has an incentive structure heavily biased, if not to the deliberate creation of inflation, then certainly towards taking inflationary risks which the electorate, if fully informed and consulted on this issue in isolation, would in all likelihood reject. ${ }^{26}$

This, as the reader will at once recognise, is the basis of the traditional case for taking the conduct of monetary policy out of the political sphere, and for granting what is usually referred to as "independence" to the central bank; but, if the bank is also to be democratically accountable, this word cannot be taken to mean free of all political oversight and control. Nor should it, for the case that I have outlined is against only one particular kind of oversight and control mechanism, namely rendering monetary policy completely subservient to the political processes of representative democracy. That case is quite specific about institutional sources of inflationary bias in monetary policies, and the implied solution to the problems thus generated is therefore just as specific: insulate the act of money creation from the pressures of day to day politics. As Louis Rasminsky put it, "the power to print money should be kept clearly separate from the power to spend money".

There is a large middle ground between complete subservience of monetary policy to politics at one extreme, and complete freedom from political oversight on the other. Politically imposed monetary policy rules are located in just that middle ground. They provide a framework within which democratic accountability for the broad strategy of monetary policy may be combined with the insulation of its day-to-day tactics from 
extraneous and damaging political pressures. ${ }^{27}$ In the design of such rules, the central bank's responsibilities should not, of course, be specified in terms so vague as to risk rendering unanswerable in practice the question as to whether or not they have been met. If they are to be meaningful, performance criteria must be specified in terms of well defined and easily measurable variables, such as the price level, or money growth.

The former choice would make the Bank accountable for the outcome of policy, and the latter for the behaviour of an intermediate target variable. One factor in this choice would be the extent to which failure to meet goals provided an occasion, on the one hand, to punish those responsible, and on the other, to force a change in policy with a view to improving it. If sanctions are to be imposed for failure, there is much to be said for waiting for price level data to reveal that some public harm has been done; if triggering a change in policy is the goal, then holding the central bank responsible for meeting money growth targets at first sight seems more attractive.

There are, however, two problems with politically imposed money growth rules. The first has already been discussed: namely, the difficulty of providing for the effects of institutional change on the effectiveness on any particular rule without simultaneously writing it so vaguely as to render it nugatory as a constraint on policy. The second, probably more important, is that the general public, on whose support the durability of any democratically imposed rule must depend, probably does not understand the relationship between money growth and inflation, and therefore cannot be relied upon to care much about how closely a rule for its behaviour is in practice observed. Though the money growth targeting that was much practised in the 1970s and 1980s stopped far short of being rule-guided in the sense under discussion here, its history does reveal two relevant 
features: targets were more often overshot than observed, and outside of such specialist groups as the academic community, the financial press, and participants in financial markets who used such information as an input to forecasting the future stance of policy, no-one took much notice. A rule that the electorate neither fully understands nor cares much about is unlikely to be imposed democratically in the first place, and, if it were imposed, it would not be binding for very long.

The inflation rate is something which affects the economic welfare of the general public and therefore commands its attention, and which the monetary authorities ultimately control. It is, then, a natural object for a rule based policy regime which insulates monetary policy from day to day pressures while leaving room for accountability, and it is no accident that this is precisely the solution towards which a number of countries have been moving in recent years. Even if the accountability provisions of that regime go no further than requiring the central bank to report regularly and publicly on its performance relative to the goals it has been set, then having them cast in terms of price level behaviour at least makes it likely that the audience for that report will be large, attentive, and critical. If the regime goes further, and incorporates the threat of sanctions against policymakers who fail to meet their assigned goals, and if those policymakers are left free to use their best judgement in trying to abide by them, they themselves will have even more incentive to discover the operating procedures most likely to succeed in doing so. If money growth is indeed crucial to the behaviour of the price level, for example, a central banker who is likely to be publicly embarrassed and whose career is likely to suffer if the price level misbehaves will discover this and make use of it without needing to be required to do so by supplementary legislation; and if money growth is not, by itself, 
a reliable leading indicator of inflation, it would hardly be fair to require a central banker to achieve a time path for it in addition to meeting inflation targets. Here again, however, the desirability of frequent public discussion of central bank operating procedures becomes apparent. Not only is it desirable that the private sector be kept aware of what monetary policy is doing so that its decision-making is improved. It is equally desirable that the central bank remains open to discussion and criticism of its activities so that its chances of discovering the most effective operating procedures are increased.

\section{Concluding Observations}

The foregoing arguments are easily summarised. Price level behaviour is both important to the general public and subject to the control of the monetary authorities; and it is also a legitimate matter for democratic debate. Since low inflation seems to promote economic efficiency in a market economy, there is a strong case to be made for holding the monetary authorities accountable to the electorate for achieving it, or, more controversially, price stability. If those in charge of executing monetary policy are to be held accountable for its outcome, however, they must be left free to exercise discretion, in the sense of their best judgement, in its execution.

The natural way to put such a policy regime in place would be an appropriately drafted central bank law. A goal for price level behaviour would be the main, thought not necessarily the only, feature of a clause defining the institution's mandate; while other clauses would lay down rules for the internal governance of the bank, and the terms on which its officers were appointed, designed to ensure them security of tenure in the face of political pressures, (always subject to the possibility that they could be removed from 
office for outright incompetence or malfeasance). The details of such a law would differ from country to country, because it would have to dovetail with other features of political arrangements, but it would be reasonable to use a now considerable body of empirical work, among which Alex Cukierman's (1992) monograph stands out for its thoroughness, as a source of information about just which specific features of central bank laws seem most likely to lead to policy autonomy and the pursuit of low inflation.

Even so, a law, no matter how carefully drafted, is only the starting point for a policy regime. It does not, in and of itself, guarantee a particular outcome, as the abovementioned empirical work has shown. Though the degree of political autonomy enjoyed by the central bank does seem, on average, to be inversely correlated with inflation, this result is nevertheless heavily conditioned by the experiences of two or three countries:the German Federal Republic, Austria, and Switzerland. It is worth recalling, as Meino (1994) has noted, that the Bank of Japan, whose success in controlling inflation has been as great as any, operates under a law which, as a result of successive amendments, is unclear to the point of internal inconsistency on this very matter. Moreover and paradoxically, the very vulnerability of the Bank of England to political control, built into the legislation under which it operates, made it much easier for the then recently elected Thatcher government to introduce its stabilization programme in the early 1980 s.

As to the question of the influence of the Central Bank's mandate on its performance, it is well known that the mandate of the Swiss National Bank is just as much a model of muddle and ambiguity as are those of Germany and Austria paradigms of clarity. In any event, the matter of a Bank's mandate has more to do with ensuring its accountability for its actions than anything else. If accountability is to amount to no more 
than regular public hearings before legislative committees, with the prospect of public embarrassment if performance has been bad, then the type of language usually (and appropriately) found in Central Bank laws, requiring the preservation of the "stability of the currency" or some such generality may provide a sufficient basis for it. But if accountability involves sanctions, such as dismissal of officials who have failed to meet their goals, then the goals in question surely need to be defined with a degree of quantitative precision about the behaviour of a precisely defined statistical series, that it would be inappropriate to write into a quasi-constitutional document such as a Central Bank Law. Some supplement to that law, such as the explicit contract that exists between the Government of New Zealand and the Reserve Bank, would be called for. ${ }^{28}$

None of this is to argue that a clearly written Central Bank law is irrelevant. For a political entity starting from scratch with a central bank as is the European Union, a clear law is, on the contrary, probably a necessary condition for successful monetary policy. Necessity and sufficiency are not the same things, however, and as Issing (1993) has emphasized no monetary policy regime is going to endure in an otherwise liberal democracy without at least the acquiescence, and better the support, of the electorate. For such support to be forthcoming, accountability on the part of the monetary authorities is a sine qua non. At the very least the whys and wherefores of current policy must be continuously open to public question, and the possibility that policy, and perhaps policy makers too, can ultimately be changed if those questions are not answered satisfactorily must be guaranteed. The precise means whereby day-to-day autonomy of the monetary authorities can be combined with their longer run accountability for their actions cannot be discussed in a vacuum. What will work under a Westminster style parliamentary 


\section{1}

system is unlikely to be transferred easily to an American presidential-congressional framework; a federal state needs to address the interests of junior governments with measures that will be irrelevant in a unitary state; regionalism is more important in some jurisdictions than others; and so on. ${ }^{29}$ Other papers for this conference will take up these matters on a case by case basis, but it is hoped that the general principles set out here will help provide an overall context for their discussion. 


\section{ENDNOTES}

*Paper presented at Session I (Explorations of a Framework for Effective Monetary Policy) of a Conference "Towards More Effective Monetary Policy" held at the Bank of Japan, October 26-27, 1995. I am grateful to John Crow, Peter Howitt, David Longworth, Alvin Marty, Allan Meltzer, Michael Mussa, Michael Parkin, and Bill Robson, and to participants in a Faculty Seminar at the Department of Economics, McGill University as well as the Political Economy Workshop at the University of Western Ontario for many helpful comments. Loretta Nott provided able research and bibliographic help. I remain solely responsible for the views presented here.

1. I am well aware that, for nations introducing new currencies, some of those nations themselves, as in Eastern Europe and the Baltic, being new, a fixed exchange rate on some pre-existing stable currency, perhaps underpinned by a currency-based arrangement is an attractive, perhaps even a necessary, means of creating credibility for the new currency (see Selgin (1994) for a discussion).

2. See Allan Meltzer's (1995) contribution to this conference for an insightful discussion of the international dimension of inflation control issues.

3. Among the studies I have in mind were those of central European hyper-inflations (Cagan) and the Confederacy (Lemer) (in Friedman (ed.), 1956), those of Argentina (Diz), and Chile (Deaver)Post-war Japan (Keran) South Korea and Brazil (Campbell) in Meiselman (ed.) (1970).

4. The locus classicus for this theoretical framework (without, however, the Phillips curve) were Friedman's essays of the early 1970s, whose most accessible source is R.J. Gordon (ed.) (1974). I have discussed this material, and the neglect of the Phillips curve in it, though not in Friedman (1968), in Laidler (1995).

5. And, as Allan Meltzer has reminded me, in the 1960 s monetary policy was often regarded as capable of contributing to a variety of other goals too--e.g. the provision of cheap housing finance, whose pursuit would be interfered with if policy was directed to bringing down inflation.

6. Even before the publication of Friedman's 1969 essay, this line of reasoning was being developed by Harry Johnson $(1968,1969)$.

7. Tobin's fullest exposition of his views on inflation-unemployment interaction appeared in his 1971 Presidential Address to the American Economic Association (Tobin 1972). Note that the kind of argument later advanced by Monetarists against this position, e.g. by Brunner and Meltzer (1993), were already implicit in earlier work by these authors (e.g. 1964, 1971). I have discussed this strand of monetarist analysis in Laidler (1995). See also the next section of this paper. 
8. And, as Brunner and Meltzer (1993) have stressed, it remains an accurate characterisation of Real Business Cycle models too.

9. The phrase "shoe-leather costs" seems to derive from Tobin's (1972) discussion of the relatively trivial costs associated with inflation in then conventional analysis. Three of the early papers which questioned this analysis were presented at IEA conferences in 1975 though not published until later: Jaffe and Kleiman (1978), Laidler (1978), and Leijonhufvud (1977)). These papers differed in many details and matters of emphasis, and it should be noted that Laidler's in particular built upon Brunner and Meltzer (1971). The UCLA tradition, of which Leijonhufvud's ideas formed a part had, of course, already had influence on Brunner and Meltzer in the $1960 \mathrm{~s}$.

10. Phenomena such as these are present in much more acute forms under conditions of what Heymann and Leijonhuvud (1995) call "high inflation". It is an interesting question, requiring much further investigation, whether the conditions they describe are qualitatively different from, or merely more extreme versions of, those obtaining in mild inflations.

11. See, also the contributions to two important conferences sponsored by the Federal Reserve Bank of Cleveland on Price Stability (1991) and Inflation Uncertainty (1993) for another cross section of opinions on these issues. These volumes display more agreement about the damaging effects of high and fluctuating inflation than about the desirability of inflation's complete elimination.

12. Inflation expectations were significant in monetarist analysis from the outset, notably as an argument of particular importance in the demand for money function in conditions of rapidly rising prices. In this context, following Cagan (1956), they were usually modelled in terms of the error-learning hypothesis. Even so, before the arrival of the rational expectations hypothesis on the macroeconomic scene in the early 1970s, monetarist analysis of inflation-output interaction was seldom based on a mechanical application of error learning. For example, in Friedman's (1968) application of the concept to the Phillips curve, explicitly adaptive expectations were conspicuous by their absence, and in other monetarist discussions of the early 1970 s this formulation was treated as at best a rough and ready starting point for getting to grips with the role of expectations in the inflationary process, prior to making allowances for other important situation specific effects, for example in open economies, of devaluations and exchange rate regime shifts. See, for example, Carlson and Parkin (1975) (written in 1971-72) for a telling counter-example to the widespread belief that, before the advent of rational expectations, macroeconomics was content with unthinking applications of mechanical error learning formulae.

13. As Taylor (1993) noted, there was a consensus on the importance of credibility for the effective work of monetary policy at the 1991 Bank of Japan Conference. Blackburn and Christensen (1989) remains an extremely useful survey of the 
literature on credibility issues as they arise in the context of monetary policy.

14. This is the conclusion that emerges from Howitt's (1990) survey of these issues. See also Konieczny (1995) and Marty and Thornton (1995). See below p. 16.

15. Closely related to these considerations are those raised by models in the tradition of Barro and Gordon (1983) in which the more credible the public find the central bank's commitment to price stability, the greater is the payoff to the bank in terms of output and employment effects from covertly abandoning the commitment in question, with a consequent long run failure to achieve a socially optimal policy. This literature leads to the insight, associated particularly with Walsh (1995), that contractual mechanisms precommitting the central bank to a more socially desirable policy might be necessary. The argument presented here follows McCallum (1995) in presuming that central banks can follow that desirable policy of their own accord and do not need to be forced to do so as well as in expression doubts about whether, in practice, any central bank actually has enough quantitative knowledge to be able to execute the type of policies which this literature presumes to be feasible. This is, of course, not to say that contractual mechanisms of the type used in New Zealand, and referred to earlier, are either uninteresting or unhelpful.

16. On this issue, see Scarth (1994), Fillion and Tetlow (1994) and Hendry (1994), who discuss the special case of this issue concerned with the choice between price level stability and zero inflation.

17. I am grateful to Bill Robson for this argument.

18. For this reason, I much prefer McCallum's (1995) term "negligible inflation" to "zero inflation" in this context, since it carries no aura of spurious precision.

19. I am indebted to Chris Green for injecting this note of sanity into my thoughts on policy credibility.

20. The only thing that might be controversial here is the choice of variable to be subjected to a rule. There are still some who advocate the maintenance of a stable and low level of nominal interest rates, or a stable and low unemployment rate. To oppose policy rules such as these is not to oppose rules in general, but only those that are not technically feasible. We have moved beyond the monetarism of twenty five years ago, but one aspect of that doctrine that still remains valid: namely, that plans for the outcome of monetary policy had better be formulated with respect to the price level or the inflation rate since this is the only variable over which such policy has any systematic long term influence.

21. It is at this point that the "Free Banking" literature comes into contact with that dealing with monetary rules. On this matter, see Selgin and White (1994). 
22. Note that Meltzer's arguments differ from Bagehot's to the extent that the latter also looked to high interest rates to generate gold inflows to bolster the banking system's reserves.

23. I am less enthusiastic about pushing such transparency to the point of having the process of arguing out the pros and cons of particular policy measures itself subject to public scrutiny.

24. See Scott Gordon (1961) for an exposition of the case for subjecting monetary policy to the same degree of democratic control as any other policy.

25. This conclusion probably applies best to economies which have experienced only moderate inflations. There is ample evidence that high and hyper-inflation generates strong incentives for ordinary members of the public to acquire enough economic understanding to cope with the phenomenon. The time and effort that must be devoted to this acquisition is one of the many costs which inflation can impose upon the economy. On these issues as they arise in conditions of high inflation, see Heymann and Leijonhufvud (1995).

26. Notice that the argument presented here hinges upon the application of "public choice" analysis to the workings of political processes particularly as they apply to so-called interest groups. The literature referred to earlier, in the tradition of Barro and Gordon (1983), which focuses instead on policy games played between a central bank and the public, and provides the analytic foundations for much contemporary formal analysis of central bank independence seems to me to pay insufficient attention to these considerations. Eijffinger and de Haan (1995) is an extremely useful survey dealing both with this literature and some of that more firmly rooted in the public choice tradition.

27. One regime that is ruled out by considerations of accountability is an irrevocably fixed exchange rate on some foreign currency. It should be made explicit that this observation does not in any way amount to a case against such emerging arrangements as the single European currency. What it does do is warn that such an arrangement needs to be viewed in the context of an altogether broader movement towards political integration.

28. My own inclination is to think of precisely defined quantitative targets on the New Zealand or Canadian model as desirable features for a policy regime in transition from significant to negligible inflation, when it is important to establish credibility for the monetary authorities. Once negligible inflation has been firmly established, it seems appropriate to induce the general public to ignore the inflation rate in its decision making. That, it seems to me, can best be done by removing quantitative targets for the variable from centre stage in public discussion. At this point, a clear, but rather general, price stability mandate written to the Central Bank Law seems to be called for. 
29. I discussed these issues in a specifically Canadian context in Laidler (1991). Since I have referred to the newly emerging European system of central banks at several points in this paper, perhaps I should also record my dismay at the lack of attention that has been paid to ensuring its political accountability, and my concern that this will prove to be a serious obstacle to its ultimate success. 


\section{REFERENCES}

Bagehot W. (1873) Lombard Street, A Description of the Money Market (London: P.S. King.

Bailey M. J. (1956) 'The Welfare Costs of Inflationary Finance.' Journal of Political Economy 64 (Feb.): 93-110.

Bank of Canada (1994) Economic Behaviour and Policy Choice under Price Stability (Ottawa: Bank of Canada).

Barro R.J. and Gordon D.B. (1983) 'A Positive Theory of Monetary Policy in a Natural Rate Model.' Journal of Political Economy 91 (Aug.): 589-610.

Blackburn K. and Christensen M. (1989) 'Monetary Policy and Policy Credibility: Theories and Evidence.' Journal of Economic Literature 27 (March): 1-45.

Brunner K. and Meltzer A.H. (1964) 'Some Further Investigations of Demand and Supply Functions for Money.' Journal of Finance 19 (May): 240-283.

(1971) 'The Uses of Money: Money in the Theory of an Exchange Economy.' American Economic Review 61 (Dec.): 784-805. (1993) Money and the Economy: Issues in Monetary Analysis (Cambridge: Cambridge University Press for the Raffaele Mattioli Foundation).

Cagan P. (1956) 'The Monetary Dynamics of Hyperinflation.' In M. Friedman (ed.) (1956).

Carlson J. and Parkin J. M. (1975) 'Inflation Expectations.' Economica NS 42: 123-138. Crow J. W. (1988) 'The Work of Canadian Monetary Policy.' Bank of Canada Review (Feb.): 3-17. 
Cukierman A. (1992) Central Bank Strategy, Credibility and Independence: Theory and Evidence (Cambridge Mass.: MIT Press).

Eijffinger S. and de Haan J. (1995) 'The Political Economy of Central Bank Independence.' (University of Tilburg: mimeo).

Federal Reserve Bank of Cleveland (1991) Price Stability (Special Issue of Journal of Money, Credit and Banking 23 Aug. pt. 2). (1993) Inflation Uncertainty (Special Issue of Journal of Money Credit and Banking 25 Aug. pt. 2).

Fillion J-F and Tetlow R. (1994) 'Zero Inflation or Price Level Targeting? Some Answers from Stochastic Simulations on a Small Open-Economy Macro Model.' In Bank of Canada (1994).

Fischer S. (1993) 'Lessons from Moderate Inflation.' In K. Shigehara (ed.) Price Stabilisation in the 1990s (London: Macmillan.

(1994) 'Modern Central Banking.' In F. Capie, C. Goodhart, S. Fischer, and N. Schmidt The Future of Central Banking (Cambridge: Cambridge University Press).

Fortin P. (1990) 'Do We Measure Inflation Correctly?' in R.G. Lipsey (ed.) Zero Inflation: The Goal of Price Stability (Toronto: C.D. Howe Institute).

Friedman M. (ed.) (1956) Studies in the Quantity Theory of Money (Chicago: Univ. of Chicago Press).

(1959) 'The Demand for Money - Some Theoretical and Empirical Results.' Journal of Political Economy 67 327-351. (1960) A Program for Monetary Stability (New York: Fordham Univ. Press). 
(1968) 'The Role of Monetary Policy.' American Economic Review 68 (March) 1-16. (1969) The Optimum Quantity of Money (London: Macmillan).

Gordon H. S. (1961) 'The Bank of Canada in a System of Responsible Government.' Canadian Journal of Economics and Political Science 27 (Feb.) 1-22.

Gordon, R. J. (ed.) (1974) Milton Friedman's Monetary Framework (Chicago: Univ. of Chicago Press).

Gray J. (1978) 'On Indexation and Contract Length.' Journal of Political Economy 86 (Feb.) 1-18.

Hendry S. (1994) 'Zero Inflation and Price Stability Monetary Policies.' UWO mimeo. Heymann D. and Leijohnhufvud A. (1995) High Inflation (London: Oxford University Press).

Howitt P. W. (1990) 'Zero Inflation as a Long Run Target for Monetary Policy.' In R. G. Lipsey (ed.) Zero Inflation: The Goal of Price Stability (Toronto: C. D. Howe Institute).

Issing O. (1993) Central Bank Independence and Monetary Stability (London: IEA).

Jaffe D. and Kleiman E. (1978) 'Welfare Implications of Uneven Inflation.' in E. Lundberg (ed.) Inflation theory and Anti-inflation Policy (London: Macmillan).

Johnson H. G. (1968) 'Problems of Efficiency in Monetary Management.' Journal of Political Economy 76 (Sept.-Oct.) 971-990.

(1969) 'Inside Money, Outside Money, Income, Wealth and Welfare in Monetary Theory.' Journal of Money, Credit and Banking 1 (Feb.) 30-45. 
Konieczny J. (1994) 'The Optimal Rate of Inflation: Competing Theories and Their Relevance to Canada.' In Bank of Canada (1994).

Laidler D. (1978) 'The Welfare Costs of Inflation in Neoclassical Theory-Some Unsettled Problems." In E. Lundberg (ed.) Inflation Theory and Anti-inflation Policy (London: Macmillan). (1991) How Shall We Govern the Governor? (Toronto: C.D. Howe Institute). (1995) 'Monetarism circa 1970 - a View from 1994.' Kredit und Kapital 28: $323-345$.

Leijonhufvud A. (1977) 'Costs and Consequences of Inflation.' In G. C. Harcourt (ed.) The Microeconomic Foundations of Macroeconomics (London: Macmillan).

Lucas R. E. Jr. (1972) 'Expectations and the Neutrality of Money.' Journal of Economic Theory 4: 103-124.

Marty A. and Thornton D. (1995) 'Is There a Case for "Moderate" Inflation?' Federal Reserve Bank of St. Louis Review 77 (July/August): 27-37.

Mayer T. (1978) The Structure of Monetarism (New York: W. W. Norton).

McCallum B. T. (1988) 'Robustness Properties of a Rule for Monetary Policy.' in K. Brunner and B. T. McCallum (eds.) Money Cycles and Exchange Rates: Essays in Honour of Allan H. Meltzer Carnegie-Rochester Conference Series Vol. 29 (Amsterdam: North Holland).

(1995) 'Inflation Targeting in Canada, New Zealand, Sweden, the United Kingdom, and in General.' Paper presented at 7th Bank of Japan International Conference (this volume). 
Meino Y. (1992) 'Issues Facing the Japanese Economy and Roles of Central Banks.' (Speech given by the Governor of the Bank of Japan at Research Institute of Japan.) Bank of Japan (mimeo).

Meiselman D. (ed) (1970) Varieties of Monetary Experience (Chicago: Univ.of Chicago Press).

Meltzer A. H. (1987) 'On Monetary Stability and Monetary Reform.' Bank of Japan Monetary and Economic Studies 5 (Sept.): 13-34.

(1994) 'Regulatory Arrangements, Financial Stability and Regulatory

Reform.' Bank of Japan Monetary and Economic Studies 12 (July): 1-15. (1995) 'On Making Monetary Policy More Effective Domestically and Internationally.' Keynote Address, 7th Bank of Japan International Conference (this volume).

Menger C. (1892) 'On the Origin of Money.' Economic Journal 2 (June): 239-255.

Muth J.R. (1961) 'Rational Expectations and the Theory of Price Movements.' Econometrica 29: 315-335.

Phelps E.H. (1967) 'Phillips Curves, Expectations of Inflation and Optimal Unemployment over Time.' Economica NS 34 (Aug.): 254-281.

Sargent T. J. and Wallace N. (1976) 'Rational Expectations and the Theory of Economic Policy.' Journal of Monetary Economics 2 (May): 169-183.

Scarth W. (1994) 'Zero Inflation versus Price Stability in Bank of Canada.' (1994).

Selgin G. (1994) 'On Ensuring the Acceptability of a New Fiat Money.' Journal of Money Credit and Banking 26 (Nov.): 808-826. 
and White L. H. (1994) 'How would the Invisible Hand Handle Money?'

Journal of Economic Literature 32 (Dec.): 1718-1749.

Simons H. (1936) 'Rules versus Authorities in Monetary Policy.' Journal of Political Economy 44 (Feb.): $1-30$.

Smith A. (1776) The Wealth of Nations London.

Taylor J.B. (1993) 'Price Stabilisation in the 1990s: An Overview.' In K. Shigehara (ed.) Price Stabilisation in the 1990s (London: Macmillan).

Tobin J. (1972) 'Inflation and Unemployment.' American Economic Review 82 (March): $1-18$

Walsh C. (1995) 'Optimal Contracts for Central Bankers.' American Economic Review 85 (March): 150-167. 